\title{
A HISTOPATHOLOGICAL STUDY OF NEOPLASTIC LESIONS OF CONJUNCTIVA
}

\author{
Dr. Urvashi Gupta ${ }^{1}$, Dr. Ruchi Shrestha ${ }^{2}$, Dr. Ashok P Samdurkar ${ }^{3}$, Dr.Anita Shahi ${ }^{4}$
}

\begin{abstract}
BACKGROUND:

Ocular malignant tumors are relatively rare compared to other eye lesions, require immediate diagnosis and management. But ignorant care due to unawareness of persons can result into debility, loss of vision, and occasionally life is jeopardized. ${ }^{1}$ The aim of the study is to determine the frequency of most common neoplastc lesions of conjunctiva with histopathologically confirmed diagnosis.
\end{abstract}

\section{MATERIAL AND METHODS:}

It was a retrospective cross-sectional study done in a period of two years (January 2011 December 2012) that included 120 patients who presented with conjunctival lesions to the pathology department of Universal College of Medical Science, Bhairahawa, Nepal.

\section{RESULTS:}

In this study out of 120 biopsies which were histopathologically diagnosed as conjunctival neoplasms were categorized into benign, dysplastic and malignant lesion and was common after second decade of life. Majority of cases (75 cases, $62.5 \%)$ were categorized as benign lesion with predominance of squamous papilloma $(n=25)$ and nevus ( $n=21)$, followed by malignant lesion (27 cases, 22.5\%) and dysplastic lesions (18 cases, 15\%). Amongst malignancies, squamous cell carcinoma (SCC) was the most prevalent and a case of malignant melanoma was studied. Dysplastic lesion included conjunctival intraepithelial neoplasia (CIN) with and without squamous papilloma.

\section{CONCLUSION:}

Histopathology plays an important role in diagnosis of conjunctival lesions and rules out different categories of neoplastic lesions on routine basis. In this study Squamous cell carcinoma (SCC) $20.01 \%$ is the most common malignant tumor of conjunctiva. The next majority of cases diagnosed as the verrucuous carcinoma $1.66 \%$ and malignant melanoma $0.83 \%$ maximum case of malignant cases diagnosed in the age group of more than 50 years.

KEYWORDS: Conjunctival tumors; Squamous cell carcinoma

1. Pathologist, Universal College of Medical Sciences, Bhairahawa, Nepal

2. Ophthalmologist, Lumbini Eye Institute, Bhairahawa, Nepal

3. Prof. Pathologist, Universal College of Medical Sciences, Bhairahawa, Nepal

4. Lecturer Pathologist, Universal College of Medical Sciences, Bhairahawa, Nepal

\author{
For Correnpondance \\ Dr Urvashi Gupta \\ MD Pathology \\ Universal College of Medical Sciences \\ Bhairahawa,Nepal \\ Email: drurvashig@gmail.com
}




\section{INTRODUCTION:}

Ocular malignant tumors are relatively rare compared to other eye lesions, require immediate diagnosis and management. But ignorant care due to unawareness of persons can result into debility, loss of vision, and occasionally life is jeopardized. ${ }^{\text {The }}$ aim of this study was to determine the frequency of most common conjunctival lesions with histopathologically confirmed diagnosis.

The conjunctiva is a thin mucous membrane that lines the inner surface of the eyelids and most of the anterior surface of the ocular globe. The conjunctival epithelium is composed of two to five layers of columnar cells that rest on a continuous basal lamina. This epithelium contains mucin-secreting goblet cells and menaocytes.

Tumors of the conjunctiva and cornea comprise a large and varied spectrum of conditions. These tumors are grouped into two major categories of congenital and acquired lesions. The acquired lesions are further subdivided based on origin of the mass into surface epithelial, melanocytic, vascular, fibrous, neural, histiocytic, myxoid, myogenic, lipomatous, lymphoid, leukemic, metastatic and secondary tumors. ${ }^{3}$

\section{MATERIAL AND METHODS:}

This study was a retrospective cross-sectional study done in a period of two years (January 2011 December 2012) that included 120 patients who presented with conjunctival lesions to the pathology department of Universal College of Medical Science, Bhairahawa and provided informed consent for the enrollment of study. All type of tumor and tumor like lesion in conjunctiva of either sex, any age group were included excluding inflammatory condition of conjunctiva. A semi structured performa were especially drafted for the study, containing all the clinical details of the patient relevant to the study especially, right or left eye specimen, types of specimen, mode of onset, duration at presentation, progression of disease, gross examination include measurement, shape, surface, consistency, colour of the lesions. The specimens were fixed in $10 \%$ formalin, routinely processed and stained with hematoxylin \& eosin, and special stains were used as and when required. The diagnoses were confirmed with the help of light microscope by two pathologist. The tumor grading was done according to the recent classification given by the $\mathrm{ICMR}^{4} /$ Silverberg Delelis $3^{\text {rd }}$ edition, ${ }^{4}$ and was diagnosed as neoplastic lesion which was further categorized into benign, dysplastic and malignant lesion. All data thus obtained were noted on socio-demographic and clinical data sheets.

\begin{tabular}{|c|c|c|c|c|c|c|c|c|}
\hline \multirow[b]{3}{*}{ Gender } & \multirow[b]{3}{*}{ group } & \multicolumn{6}{|c|}{ Classify } & \multirow{3}{*}{ Total } \\
\hline & & \multicolumn{2}{|c|}{ Benign } & \multicolumn{2}{|c|}{ Dysplasia } & \multicolumn{2}{|c|}{ Malignant } & \\
\hline & & $\mathrm{n}$ & $\%$ & $\mathrm{n}$ & $\%$ & $\mathrm{n}$ & $\%$ & \\
\hline \multirow{6}{*}{ Male } & $<20$ years & 10 & 8.33 & 1 & 0.83 & 3 & 2.5 & 14 \\
\hline & 21-30 years & 8 & 6.66 & 2 & 1.66 & 1 & 0.83 & 11 \\
\hline & $31-40$ years & 3 & 2.5 & 2 & 1.66 & 0 & 0.0 & 5 \\
\hline & $41-50$ years & 3 & 2.5 & 1 & 0.83 & 1 & 0.83 & 5 \\
\hline & $>50$ years & 9 & 7.5 & 0 & 0.0 & 5 & 4.16 & 14 \\
\hline & Total & 33 & 27.49 & 6 & 4.98 & 10 & 8.32 & 49 \\
\hline \multirow{6}{*}{ Female } & $<20$ years & 12 & 10.0 & 1 & 0.83 & 5 & 4.16 & 18 \\
\hline & $21-30$ years & 9 & 7.5 & 1 & 0.83 & 1 & 0.83 & 11 \\
\hline & $31-40$ years & 5 & 4.16 & 4 & 3.33 & 4 & 3.33 & 13 \\
\hline & $41-50$ years & 7 & 5.83 & 4 & 3.33 & 1 & 0.83 & 12 \\
\hline & $>50$ years & 9 & 7.5 & 2 & 1.66 & 6 & 5.0 & 17 \\
\hline & Total & 42 & 34.99 & 12 & 9.98 & $\begin{array}{c}17 \\
14.1\end{array}$ & & 71 \\
\hline
\end{tabular}

Table no.1: Distribution of the diagnostic category by age group and gender presenting as benign or malignant or dysplasia.

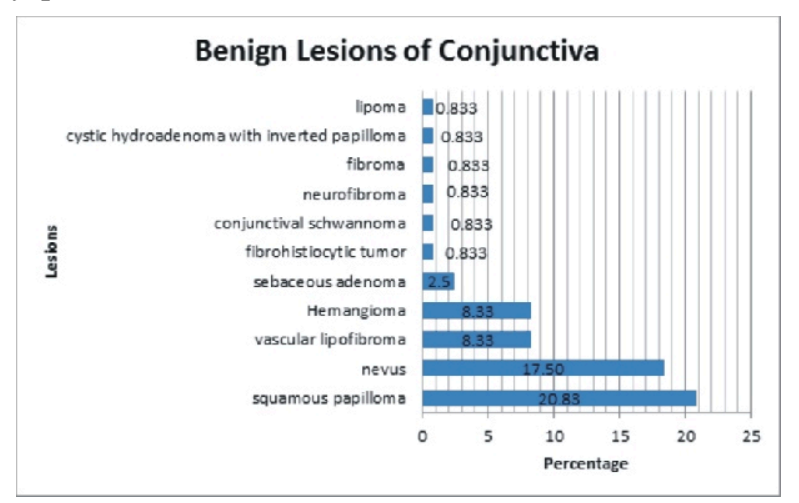

Table No.2: Prevalence of benign lesion cases of conjunctiva .

\begin{tabular}{|c|c|c|}
\hline \multicolumn{3}{|c|}{ Dysplastic lesions } \\
\hline Diagnostic category & $\mathrm{n}$ & Percentage \% \\
\hline $\mathrm{CIN}$ & 9 & 7.5 \\
\hline $\begin{array}{l}\text { CIN with Squamous } \\
\text { papilloma }\end{array}$ & 9 & 7.5 \\
\hline Total & 18 & 15 \\
\hline & \multicolumn{2}{|r|}{ Malignant lesions } \\
\hline $\mathrm{SCC}$ & 24 & 20.01 \\
\hline SCC (verrucous) & 2 & 1.66 \\
\hline Malignant melanoma & 1 & 0.83 \\
\hline Total & 27 & 22.5 \\
\hline
\end{tabular}

Table No.3: Prevalence of Dysplastic lesion and malignant lesions of conjunctiva 


\section{RESULTS:}

The analyzable data of conjunctival biopsy were 120 . Female were more affected $59.16 \%$ than male $40.83 \%$. The majority of cases were benign lesion and maximum cases reported were below the age group of 20 years in both sex male $8.33 \%$ \& female $10 \%$. The dysplasia category included predominance in females of $31-40$ years $(3.33 \%) \& 41-50$ years $(3.33 \%)$. The total malignant cases reported were more in females $(5.0 \%)$ than males (4.16\%) in fifth decade of their life (Table- 1$)$.

Out of these 120 cases benign lesions were $62.5 \%$, dysplastic and malignant cases were $15 \%$ and $22.5 \%$ respectively. The most commonl benign lesions studied was squamous papilloma $20.83 \%$, (Fig-1) and nevus $17.50 \%$ (Table-2). Out of $15 \%$ diagnosed cases of dysplastic lesion $7.5 \%$ were Conjunctival Intraepithelial Neoplasia (CIN) and rest were CIN with papilloma. Squamous cell carcinoma (SCC) $20.01 \%$ was the most common malignant tumor (Table-3) (Fig-2).

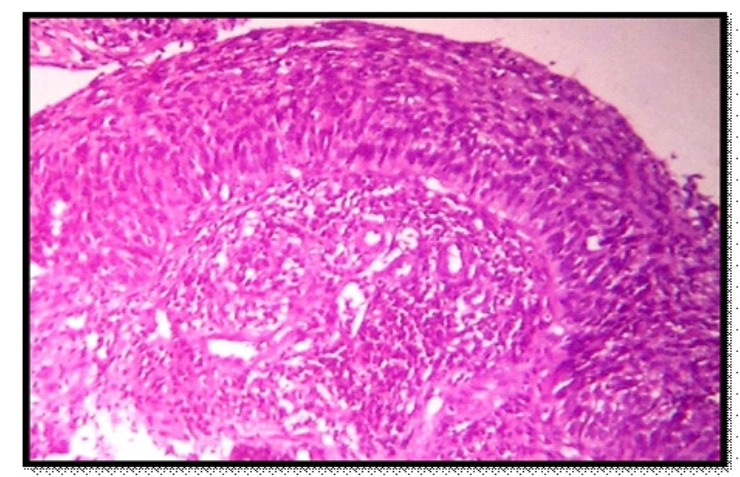

Figure 1: Squamous papilloma showing high grade dysplasia with fibrovascular core (HE stain, X400).

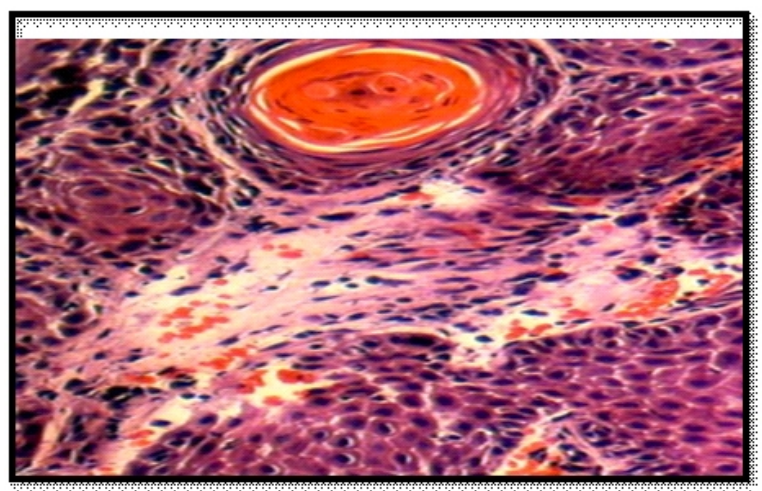

Figure 2: Invasive squamous cell carcinoma well differentiated type showing squamous pearl

(HE stain, X400)

\section{DISCUSSION:}

Nepal being a relatively small country and having inadequate manpower for better understanding the ocular pathology and newer insights into the disorder which are specific to the country. This study is very much required to gain for better treatment strategies and planning.

Various studies in the past have shown that conjuctival tumor and tumor like lesions are more common in male ${ }^{5,6,7}$ (Laila in 2011 and Fahimeh \& Amir in 2006 and Mandal et al., 2007). Female preponderance amongst conjunctival lesion like tumors was found in a Kenyatta National Hospital and Pathologists Lancet Kenya, it is almost equal to our study finding. According to Kumar R. et al., $2009^{8}$ retrospective study of 277 cases, 59 were diagnosed as malignant tumor (21.3\%) with 27 males (45.8\%) and 32 females (54.2\%), which was almost similar to our findings result. In our study mean age of patients with conjunctival tumor and tumor like lesions was more common in younger people compared to older people. Similar to Lavaju et al., $2009^{9}{ }_{2}$ majority of cases are reported at younger age groups below the age of 20 years.

In our study the commonest histopathological findings were squamous papilloma $(20.83 \%)$, nevus $(17.5 \%)$, squamous cell carcinoma (20.01\%), conjunctival intraepithelial neoplasia (7.5\%). Fahimeh \& Amir in $2006^{6}$ identified the most common primary conjunctival neoplastic lesion was nevus (38\%), followed by squamous cell carcinoma $(25.1 \%)$, papilloma (7.8\%), dysplasia (5.6\%) and hemangioma (5.1\%) which was similar to our study findings. Umar et al., ${ }^{10} 2012,438$ ophthalmic tumors were diagnosed during the study period, of which $79.7 \%$ malignant. SCC were the commonest tumors $(18.9 \%)$ reported in his study, most prevalent in $3^{\text {rd }}$ to $5^{\text {th }}$ decades, which was concordant with our study.

Though there are various studies in ocular pathology, very few are reported from this part of the country. This study finding will give some insight into this established but dynamic concept. The findings will be expected to add knowledge to better treatment plan for patient with ocular pathology.

\section{CONCLUSION:}

Histopathological evaluation plays an important role in diagnosis of conjunctival lesions and rules out different categories of neoplastic lesions on routine basis. Abnormality of squamous epithelial cells are of variable etiology and represents the predominant problematic pathology in 
conjunctival lesions and should be categorized into benign, dysplastic and malignant categories.

Squamous cell carcinoma was the most common malignant tumor of conjunctiva above the age of 50 years. Thus conjunctival tumor and tumor like lesions were more common in younger people compared to older people. Male to Female ratio was 1: 1.44 , this finding was contrary to the majority of existing findings where males were over represented in conjunctival tumor and tumor like lesions. This study aids in the early detection, diagnosis and treatment of ocular tumors before the life and vision of an individual is jeopardized.

\section{REFERENCES:}

1. Robert F. the Eye. In: Vinay kumar; Abul K. Abbas; Nelson Fausto, Jonc Aster, Robbins and Cotran Pathologic Basis of Disease. $8^{\text {th }}$ ed.Elsevier Inc; 2010. pp. 1346-1349.

2. Juan Rosai MD. Rosai and Ackerman's Surgical Pathology.10ed. Vol 2.published by Elsevier Inc. 2012. pp.24822485 .

3. Rose AS et al. Hepatic, ocular and cutaneous sarcoidosis. Clin Chest Med. 2008. 29:509.

4. Silverberg Steven G. Principles and Practice of surgical pathology and cytopathology. $3^{\text {rd }}$ ed. New York: Publisher Churchill livingstone Inc. 1997. Vol 3. pp.1582-1586.

5. Laila H and Mohamad E. A clinicopathologic study of excised conjunctival lesions. Middle east Afr J Ophthalmol.Jan-Mar; 2011. 18(1): pp.48-54.

6. Fahimeh AA and Amir BH.original researchfarabi eye hospital. The epidemiologic study of children diseases under one year. Tehran University of med sci.tehran.opthalmic epidemiology, 2006.13: pp.275-279.

7. Mandal SK, Banerjee A, Ghosh A.J. Histopathological study of conjunctival lesions. Indian med association. Apr2007. 105 (4): pp. 206-212.

8. R. Kumar, R.K. Adhikari, M.K. Sharma, D.R. Pokharel, N. Gautam: Pattern of Ocular Malignant Tumors in Bhairahawa, Nepal. The Internet Journal of Ophthalmology and Visual Science. 2009. Volume 7 Number 1. DOI: 10.

9. Lavaju P, Arya SK, Sinha A, Pandey S, Adhikari S, Shrestha BG, Chetan S, Agarwal TL. Patterns of ocular tumors in the Eastern region of Nepal. Nepal J Ophthalmol. Jan-Jun; 2009. 1(1): pp. 9-12.

10. Umar AB, Ochicha O, IIiyasu Y. A pathologic review of ophthalmic tumors in Kano, Northern Nigeria. Niger J Basic Clin Sci; 2012. 9: pp. 23-26 